\title{
The Use of Primaries by Political Parties: The Case of PASOK
}

\author{
By Gregory T. Papanikos
}

This paper examines the primary elections of the PanHellenic Socialist Party (PASOK) which were held on $5^{\text {th }}$ and $12^{\text {th }}$ of December 2021. Six candidates run for the position of the president in the first round and two runners-up in the second. As mentioned in the literature, there is a dearth of primary elections studies relative to general elections. The latter attract the attention of mass media for the obvious reason: they determine who or which party will govern the country or any other political entity. Nevertheless, there is a growing literature on primary studies. There are three aspects researched in this literature: (a) primary elections systems, (b) why a political party decides to hold primary elections and (c) the selection criteria of candidates and voters. This paper uses the existing literature to analyze some facets of the history of PASOK's primary elections, emphasizing the most recent one of 2021. The most important conclusion emerging from this analysis is that ideology did play a role, particularly the candidates' stance on their possible collaboration with the right-wing or the left-wing parties, which has been a controversial issue in the last decade. Another important conclusion is that PASOK voters opted for a younger candidate primarily because they wanted to get out of the current stalemate of PASOK's low performance in general elections. As predicted from the literature, the competition between the six candidates resulted in a large turnout on the ballot date even though other factors played a positive role such as very good weather and a wide media coverage.

Keywords: primaries, elections, voting, political parties, PASOK, Greece

\section{Introduction}

In recent years, the primary elections of political candidates and their parties have attracted the interest of the relevant literature even though general elections remain at the top of the research and media agenda. This paper contributes to the literature for primary elections by looking at one such case of a Greek political party which was the first in Greece to adopt primary elections. The PanHellenic Socialist Party (PASOK) initiated such a system in 2004. Subsequently, five more followed during the years of: 2007, 2012, 2015, 2017 and 2021. Although all are discussed in this paper, the emphasis is put on the most recent one of 2021 when 6 candidates competed for the position of the president of the PASOK party.

The paper is organized into eight sections, including this brief introduction. The next section reviews the relative literature. There are three types of studies included in this paper. Firstly, many studies have analyzed the theoretical and empirical aspects of primary political systems. In this paper, the review of this

*President, Athens Institute for Education and Research, Greece; Honorary Professor of Economics, University of Sterling, UK; and Professor, MLC Ljubljana, Slovenia. 
literature is contained within the framework of those studies which include ideology as a determining factor in selecting the system and in choosing a candidate. The reason is that this literature is very much relevant to analyzing the primary elections of PASOK, especially the most recent one in 2021. The second strand of literature explains why political parties choose to select their leader through the primary elections' mechanism. Five reasons are mentioned in the literature: (a) keep the party united; (b) mobilize membership and ideological friends; (c) chose the best candidate; (d) increase the involvement of the leader in winning the next elections; and (e) generate media attention. Finally, in the review section of this paper the selection criteria of a leader are discussed. The most important criteria appear to be ideological affinities and electability in general elections, which in many cases pose a dilemma on voters' decision.

The literature review guides the analysis of PASOK's primary elections. Four sections are devoted to this analysis (sections three to six). Section three briefly discusses the history of PASOK's primary elections. Sections four and five analyze the ideology of the candidates and the voters of the primary elections of 2021 and the voting results in more detail. The latter are discussed in terms of ideology as well the selection criteria of viability and electability. Section seven looks at the probability of success of the most controversial candidacy - that of the former President and former Prime Minister of Greece, George A. Papandreou. Section eight concludes by summarizing the main arguments.

\section{Primary Elections: A Literature Review}

The relevant literature on primary elections discusses a number of diverse issues, including the development of theoretical models and their application to specific empirical cases. A survey of this literature is given by IDEA (2017). The researcher selected three issues to briefly review: (a) the system of primary voting and its relation to ideology; (b) the reasons a political party adopts primary elections; and (c) the criteria by which candidates are chosen. This section's literature review will guide the analysis and the discussion of the primary elections of PASOK on $5^{\text {th }}$ and $12^{\text {th }}$ of December 2021.

\section{Primary Elections Systems and Ideology}

The primary elections system is a process whereby voters decide, from a range of different candidates, who will lead the party or run for public office. A distinction is made between three types of voters: party members ${ }^{1}$, members of another party and non-party affiliated members. The primary elections systems are defined according to who, from the three types of voters, is allowed to participate. Table 1 distinguishes these three primary elections system.

\footnotetext{
${ }^{1}$ May's (1973) classical paper of party activists whose motivations depend on ideology trichotomized the party activists (or members) into non-leaders, sub-leaders and leaders. Subleaders are considered as the most extreme group from an ideological point of view while the other two are more moderate.
} 
Table 1. Primary Elections System

\begin{tabular}{|l|c|c|c|}
\hline Types of Voters & $\begin{array}{c}\text { Members of the } \\
\text { Same Party }\end{array}$ & $\begin{array}{c}\text { Friends of } \\
\text { the Party }\end{array}$ & $\begin{array}{c}\text { Members of } \\
\text { Other } \\
\text { Parties }\end{array}$ \\
\hline Closed (partisan) & $\mathrm{X}$ & & \\
\hline Open & $\mathrm{X}$ & $\mathrm{X}$ & \\
\hline Blanket & $\mathrm{X}$ & $\mathrm{X}$ & $\mathrm{X}$ \\
\hline
\end{tabular}

If it is assumed that the voting system does not affect the voters' motivation to show up on the date of the ballot and vote ${ }^{2}$, then the system of primary elections has an effect on the number of people who turnout to vote. The blanket system permits all eligible voters to vote and includes members of the party, non-members and members of other parties. Such a system will maximize, ceteris paribus, the number of voters. The open system allows members and friends who are not members of other parties to participate in the election process. The closed (partisan) system permits only members to vote. In this case, fewer people turnout in a primary election process.

It is also assumed in this literature that candidates are not identical and voters can distinguish between each one of them. The candidates' differences may depend on a number of characteristics and preferences, but usually these can be summed up as ideological deviations (Westley et al. 2004) ${ }^{3}$. These differences are usually related to candidate's ideological deviations from: (a) the ideology of the median voter of the party, and (b) the ideology of the median voter of the total electorate.

As has been identified in the literature (Westley et al. 2004), a closed system is related to the success of a candidate who aspires to an extreme ideology. On the other hand, a blanket system shifts the winning candidate's ideology towards the

\footnotetext{
${ }^{2}$ This would be the case if some party members decide to boycott their party's primary elections if non-members are allowed to vote. In some cases, they might even quit the party altogether. One solution to this problem is to adopt a stepwise approach, combining two systems. For example, the party holds closed (partisan) primary elections first by selecting a list of candidates who then run in an open system of primary elections with the participation of members and friends. The Democratic Party (PD) in Italy has adopted such a system. Of course, the order can be reversed. Firstly, the candidates are selected from an open system and then partisan primary elections follow.

${ }^{3}$ In today's world of screens, the attractiveness and facial competence of a candidate may mislead the signaling extracting process of voters as it relates to left/right ideology. In an interesting paper, Herrmann and Shikano (2016) found that good looks may mislead voters to take a candidate of an extreme ideology as mainstream or moderate. Herrmann and Shikano (2016, pp. 414-415) concluded that, “... our results suggest that political extremists (or non-moderate candidates) might benefit from good looks by being perceived as less extreme by moderate voters. Thus, moderate voters should view a competent-looking extremist as less extreme (i.e., politically closer) than an incompetent looking extremist. Likewise, good-looking extremists (or non-moderate candidates) might afford a visually less extreme appearance without being perceived as moderate by their extremist core supporters. Together, this might help explain why populist right-wing parties often have good-looking, charismatic leaders. If political facial stereotypes are an electoral asset, goodlooking candidates should have greater leeway in using that asset to their advantage." However, there are other ways to discern the ideology of candidates. Bonica (2013, p. 308) developed a statistical method which uses primary contributions "...to recover accurate and reliable ideological measures from contribution data."
} 
national median voter. In between, candidates with a party mainstream ideology may win if party members and friends are the only ones who are allowed to participate. It is assumed that ideologies can be ranked as follows ${ }^{4}$ :

\section{party's median voter $>$ overall median voter $>$ opposition's median voter}

Table 2 relates the primary electoral systems to the ideological deviations of the candidates. There are two types of deviations; firstly, the deviation of the candidate from the ideology of the median voter of his/her political party in a general election, and secondly, the deviation from the ideology of the median voter of all national voters in a general election. Of course, a party which has governing aspirations would propose policies and programs which appeal to median voters of all the electorate as has been demonstrated by Downs (1957).

An extreme ideological deviation is defined as the one which is located far away from the median voter of the party. A mainstream party ideology is the one which is defined as the one which is identical with the ideology of the party's median voter's ideology and a moderate ideology as the one which lies between the party's median voter and the overall median voter ${ }^{5}$. It is assumed that ideology distribution is unimodal. A bimodal distribution requires a different analysis along the lines suggested by Downs (1957) and discussed by many others thereafter. This literature is not discussed here because it is not considered relevant to the issue discussed here.

Table 2. Primary Election System and Candidates' Ideological Deviations

\begin{tabular}{|l|c|c|c|}
\hline $\begin{array}{c}\text { Ideological Deviations } \\
\text { Primary Election System }\end{array}$ & Extreme & Mainstream & Moderate \\
\hline Blanket & & & $\mathrm{X}$ \\
\hline Open & & $\mathrm{X}$ & \\
\hline Closed & $\mathrm{X}$ & & \\
\hline
\end{tabular}

In the 1970s, Williams et al. (1976) argued that there was a dearth of research on primary voting in comparison to general elections ${ }^{6}$. Their contribution aimed at filling this gap. The authors discussed three models of voting evaluations and selection of candidates. Their study focused upon the 1972 presidential primary elections in New Hampshire, USA, which “... constituted a major test of candidate strength across a broad spectrum of political ideologies and enabled a

\footnotetext{
${ }^{4}$ If we assume that the party is left oriented, then the inequality sign has the interpretation of more left.

${ }^{5}$ Actually, this is the ideological position which a ruling party of the left or the right would aim at, as is predicted by Downs (1957). To a certain extent, there will be a convergence of ideology towards the ideology of the median voter. However, this depends on a number of variables. Curini (2015), applying an iterative algorithm, found that this tendency depends on the internal rules for candidate and leader selection. If party members elect the leader, then the leader will be free to form policies which come closer to the median voter's ideology aiming at a better performance in future general elections.

${ }^{6}$ This is still true. Relative to general elections, primary elections do attract as much media and voters' attention. One other reason is that voters at large consider primary elections as being dominated by debates between candidates who aspire to extreme ideologies as was pointed out by Kaufmann et al. (2003) and they are therefore not interested in them.
} 
nontrivial examination of voter decision-making" (Williams et al. 1976, pp. 4041). Since then, a number of studies examined the effect of ideology in the primary elections system.

Ideology is an important determinant of voting decision-making along with many other characteristics such as party size ${ }^{7}$, party organization, territory ${ }^{8}$, etc. Studies have shown that ideology is a central characteristic but the empirical evidence is inconclusive ${ }^{9}$. Shomer (2014), using a large data set of 512 parties in 46 countries, found that ideology was not statistically significant. Carroll and Kubo (2019) related the heterogeneity of party ideology to party size. The position of the party on the left-right line is of significance. In left-oriented parties, ideology plays a more important role than in right-wing parties. Westley and Calcagno (2005) argued that the political science and public choice literature have correlated the political system of primary elections to the deviation of candidates' ideology from the median voters' positions on the various ideologicallydetermined issues. Using data from primary elections in the USA over the period 1980-2000, they concluded that a more open primary is related to fewer ideological deviations, and therefore candidates spend less to win elections.

In another context, Norrander (1989) examined whether there is a difference between the ideology of those who vote in the primaries and those who vote in the general elections. She finds no difference. This is an important finding of choosing candidates who are representative of the general public. The issue of electability is also addressed. She likewise adds the issue of the ability of the candidate to govern well once they are elected. She argues that the primary elections system and the alleged ideological unrepresentativeness is not to blame and one should look at other variables.

Bochel and Denver (1983, p. 68) examined the selection of a leader in the Labour Party (UK) and concluded that “...left-wing selectors do place more emphasis on ideology and tend to support more left-wing candidates. Even though leftwingers were a minority they could have considerable influence upon the choice made. If they act cohesively and view ideology as the primary criterion in making decisions while other selectors employ a variety of criteria then clearly candidates favoured by the left will be at an advantage."

\footnotetext{
${ }^{7}$ In an early study, Lundell (2004) found that party size matters in selecting an election system. Large parties choose more centralized systems than smaller parties. He also found that north European parties adhere to a more decentralized system than the southern European political parties. ${ }^{8}$ Spies and Kaiser (2014) studied the impact of inclusion and centralization on the degree of representation of voters by political parties. The issue of centralization included national, regional and local. They associated it to the system of selecting candidates. They found differences between the selection of candidates by party elites and a more inclusive system such as the primary election system. On the other hand, Hopkin (2001) applied the experience of USA primaries to two European countries: Spain and UK. He found that party leaders were able to control the selection of party candidates. This is true, but the issue is whether party leaders are themselves selected through a primary election mechanism.

${ }^{9}$ Nielson and Visalvanich (2017), using data from USA congressional candidates, found that ideology does play a role and voters are responsive to different candidates. As a matter of fact, they found that extreme Republicans have a greater chance to win a primary and be selected as a party nominee.
} 
A key issue here is the variation of candidates' ideological differences, i.e., what are the extreme ideological stances of a candidate within one party. Or, viewed from the side of voters, how much ideological deviation could be accepted by the followers of the party or by the participants in the primary voting process. The relevant literature asserts that this depends upon the type of the primary elections system.

Why Do Parties Use Primaries?

According to the literature, political parties use primaries for the following reasons:

a) Unify the party's different factions (unifying effect)

b) Mobilize members and ideological friends which results to increasing the membership (mobilization effect)

c) Improve the selection of a better candidate or reinforce the legitimacy of an existing one (selection effect)

d) Increase the competition of candidates (incentive effect)

e) Generate media attention and publicity by sending a message to the electorate (media effect)

These effects have been theoretically discussed and empirically tested using different data sets by a number of studies - see among many others the studies by Cross et al. (2016); Faucher (2015); Hortala-Vallve and Mueller (2015); and Aragón (2014).

A political party may use a primary elections system to unify the different factions of the party, and in doing so decreases the probability of a party split. This relates to ideology in that the higher the heterogeneity of ideology, the higher the positive effect of using primary elections. Hortala-Vallve and Mueller (2015) developed a theoretical model which showed that primaries are adopted in two cases. Firstly, if there is a threat that a dissenting faction which does not agree with party elite threatens to leave the party and form another one with more homogeneous ideology and policy preferences, then the political elite may decide to settle such a dispute using a system of primary elections. Secondly, primary elections are held to make the party bigger, a winning coalition or better integration of various factions which now exist inside and outside the party. A leader may appeal to all these factions by forming a policy program that satisfies part of each faction's policy preferences. Thus, merging and integrating the various factions of an ideological space (e.g., center left) increases the chances of winning general elections.

Faucher (2015) pointed out that in the last thirty years, membership is declining. Parties have responded by decreasing the cost of membership and by increasing their participation in decision making which includes the selection of candidates to run for public office. In doing so, they increase the intra-party competition which has another important effect. Through the intra-party competition, a better candidate is chosen. For various reasons, citizens in the 
advanced democracies refrain from joining political parties and participating in the general political process. They feel disengaged from the deliberations which take place inside the party, especially in the large political parties. Using open primaries is one way of engaging citizens to political processes and decision-making. They feel that their opinion, and therefore vote, is taken into account in selecting leaders and candidates to run for public office. This is the first step for ideological friends of the party to become members.

Finally, primary elections attract the media attention, which by itself might have positive and negative effects. The positive effect depends on the quality of the debate between the candidates. If this debate is held in a civilized manner and each candidate has the opportunity to clearly state what his ideological stance and policy preferences are, then the publicity of this may be beneficial to the overall appeal of the party. However, if the competition is fierce and gets too personal, then the publicity has a negative effect on the party's image. In some cases, such bitter intra-party debates may lead to party splits which is the opposite from what one expects from a primary elections campaign.

\section{The Selection Criteria}

Voters in primary elections base their decision on a number of criteria. Ideology is one of them. In some cases, ideology may not be a decisive one. Those who participate in primary elections may choose a candidate who is not close to their ideology on the various issues, but they have a higher probability to be elected in the general election and form a government. It is only in this case of success that the party can implement its program and policies. Thus, the voter faces a dilemma: what is the best alternative? To vote for a candidate in the primary election who is close to one's ideology, or to vote for a candidate that has the highest probability of all candidates to win the next general election? If the preferred candidate on ideological grounds fails to win the next general election, then a government will be formed by the opposition winning party, which presumably has an ideology which is further away from any party candidate's ideology in the primary elections.

Abramowitz (1989) tested three models of selection criteria using data from an exit poll of presidential primary voters in Dekalb County, Georgia in March 1988. He presented three simple models based on three independent variables. The first variable is the preference of the voter. For various reasons, a voter prefers one candidate over another. This variable is called the "candidate evaluation" variable and might be affected by many other variables such as socio-demographics of the voter and/or the cultural affinity of the voter to the candidate, e.g., ideology, religion, ethnic background, education level. The second and the third variables relate to what can be called "trendy" voting behaviour. Voters vote for those who are deemed as "winners". But there are two types of them: those candidates who are favored to win the party nomination and those who are favored to win the next general election. Abramowitz (1989) calls the first variable "viability" and the second "electability". Of course, these two variables may be highly correlated. In a blanket primary election system, these two variables of "viability" and 
"electability" may not be distinguished from each other because of the large turnout of voters. At the extreme, all potential voters of the party in general elections take part in the primary elections as well.

The issue of electability was discussed by Hall and Thompson (2018). They examined the link of congressional candidates' ideology to turnout. Extreme nominees fail to win general elections, primarily because they decrease the party's share of turnout in the general elections. Extremism has two effects. Firstly, it scares away voters and they will vote for another party. Secondly, loyal party voters may decide to abstain from voting in the election altogether.

This analysis and findings are similar to what has been happening to PASOK after the 2009 general elections. Many voters thought that there was a shift of its ideology to the right by adopting austerity measures after the Great Recession beset the Greek economy in 2009, creating an unprecedented sovereign debt crisis in peace years. The mass shift of PASOK voters was caused by a perception that there was a dramatic shift in the party's ideology. In the rest of this section, an overview of the main political issues is briefly presented which determined the political debates since the first intra-party election of PASOK in 1996. I have extensively studied and published on these issues and even though I review my own published work, these works, nevertheless, cite many references which the interested reader can easily access.

Papanikos (2015a) claimed that the main reason Greece was hit so hard by the economic crisis was an overvalued Euro, and not so much the structural weaknesses of the Greek economy - such as tax evasion - that have always existed $^{10}$. The Greek exchange rate dynamics were examined in Papadopoulos and Papanikos (2002). In a book publication, Papanikos (2014a) examined all the historical details which led to the crisis, as well as the future of a leftwing party in Greece. At the Greek economic policy level, these thorny issues - both at micro and macro level - have been examined by the author of this paper in a series of papers; see Papanikos (2015b, 2014b, 2014c). The issue of regional disparities which always play a role in determining elections results ${ }^{11}$ was examined in Papanikos (2004a, 2004b). In a series of short political papers (Papanikos, 2015d2015j), I have examined the downfall of PASOK and the emergence of a left party which ruled Greece from 2015-2019 in collaboration with an extreme right-wing party even though they had the choice to collaborate with two center-left parties. These issues were important not only in the general elections, but in PASOK's primary elections. In Papanikos (2015c), I argued that a Grexit would not be catastrophic for all Greeks; some would have benefited from the exit and some would have emerged as the big winners. However, the majority of Greeks opted for staying in. I speculated that another general election would be inevitable (Papanikos 2015h) in 2015 because the issue of in or out of the Eurozone was a controversial one and was not settled by the general elections of January 2015. As I predicted in my book (Papanikos 2014a, p. 147), the government organized a referendum on the issue. Before the first elections of 2015, I wrote that, "Germany

\footnotetext{
${ }^{10}$ The controversial issue of Greek tax evasion has been discussed in Papanikos (2015b).

${ }^{11}$ Even in the primary elections, regionality plays an important role as the 2021 primary elections of PASOK demonstrate. This issue is not addressed in this paper.
} 
has sent the message that a Greek exit from the Eurozone might be the lesser of two evils" (Papanikos 2015j). This played an important role in pressuring the coalition government of left and extreme right to decide to stay in the Eurozone and yield to the demands of the other Eurozone members.

All these issues were in one way or another part of the debate of the last 25 years of Greek politics, including the primary elections of PASOK which are examined in the next section. Politicians and parties' ideology were revealed according to their stance on the issue of (a) ideology, (b) European Union and (c) Eurozone.

\section{The History of Electing a Leader}

The first leader of PASOK was Andreas G. Papandreou ${ }^{12}$. He founded the party in 1974 and had remained the leader until his death in 1996. There was no election process during this period. Andreas G. Papandreou was the undisputable leader of the party and nobody dared to challenge his power and leadership. $\mathrm{He}$ appointed, directly or indirectly, all the party executives and the candidates for all levels of general elections: for the European Parliament, the National Parliament, the Regional and Local Officers. No party congress was held for ten years after the founding of PASOK in 1974. The first party congress was held on 10 May 1984 with 2,500 congress members who were exhilarated and cheering for the President and Prime Minister Andreas G. Papandreou who spoke for three hours. Two more party congresses followed in 1990 and 1994, but Papandreou's leadership was not challenged even though in the 1990 congress there were some discussions of electing a new leader, although nothing happened. It was after Papandreou's death in 1996 that the leadership question became a real one. After 1996, all party leaders were selected by primary party elections.

\section{An Overview of the Intra-PASOK Elections Since 1996}

Table 3 shows the dates, the election system, the number of candidates and the turnout of all PASOK's elections of leaders. A few comments for each one of them are provided in this section with the exception of the 2021 primary election which is discussed in more detail in the following sections.

Overall, there were seven election processes (one with a second round of the first two candidates) of which six used the system of primary elections. Of great interest is the number of candidates in the seven elections as is also depicted in Figure 1.

\footnotetext{
${ }^{12}$ I have examined in my book (Papanikos 2019) Andreas G. Papandreou's record as an academic economist and as a prime minister.
} 
Table 3. Elections, 1996-2021

\begin{tabular}{|l|c|c|c|c|}
\hline $\mathbf{N}$ & Date & Election System & $\begin{array}{c}\text { Number of } \\
\text { Candidates }\end{array}$ & $\begin{array}{c}\text { Number of } \\
\text { Voters }\end{array}$ \\
\hline 1 & 30 June 1996 & Party Congress & 2 & 5111 \\
\hline 2 & 8 February 2004 & Primary Elections & 1 & 1020145 \\
\hline 3 & 11 November 2007 & Primary Elections & 3 & 738078 \\
\hline 4 & 18 March 2012 & Primary Elections & 1 & 236151 \\
\hline 5 & 14 June 2015 & Primary Elections & 3 & 52388 \\
\hline 6a & 12 November 2017 & Primary Elections & 9 & 211191 \\
\hline 6b & 12 November 2017 & Primary Elections & 2 & 156103 \\
\hline 7a & 5 December 2021 & Primary Elections & 6 & 270706 \\
\hline 7b & 12 December 2021 & Primary Elections & 2 & 206339 \\
\hline
\end{tabular}

Figure 1. Number of Candidates

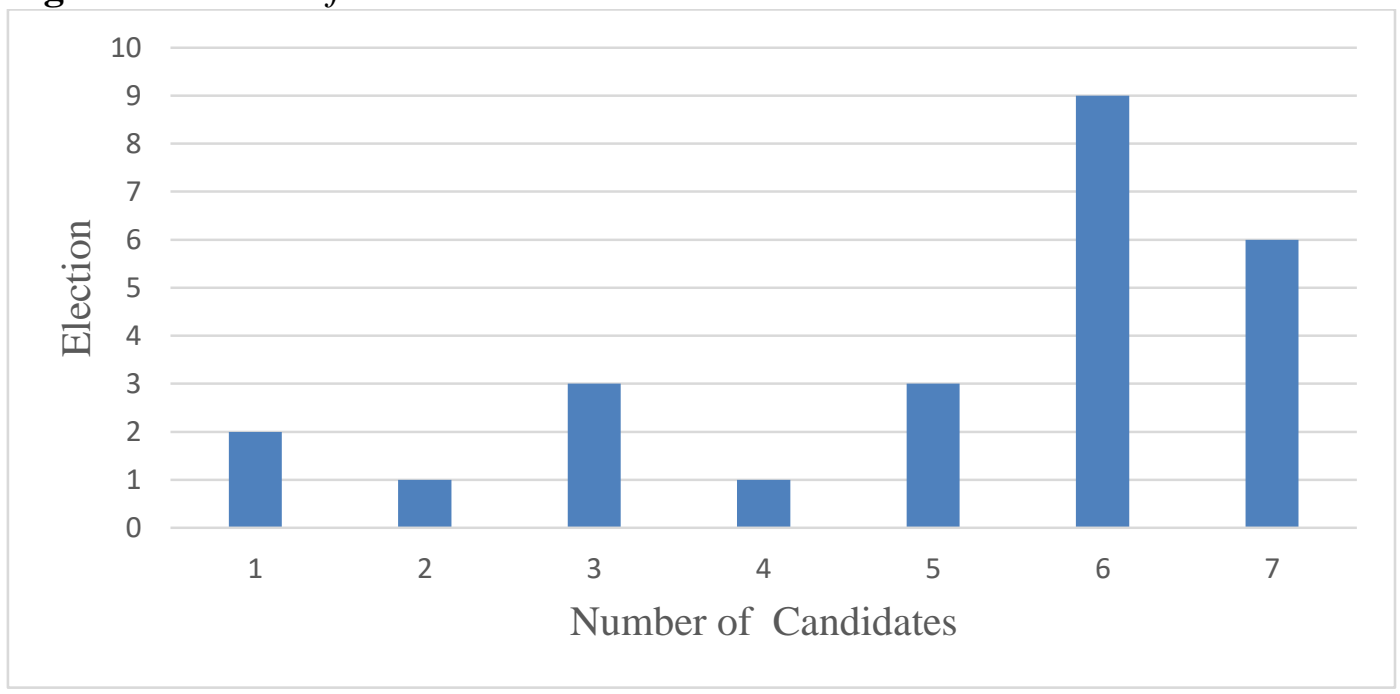

The second and fourth primary elections had only one candidate which eliminated any competition. Nevertheless, the turnout was significant for another very important reason: it was supposed to show the strength of the party, sending an optimistic signal for the next general elections. It was used as a marketing tool. As shown below, this did not work and in both cases the general elections were lost even though in the second case PASOK formed a coalition government with the right-wing party of New Democracy. It was this coalition which was considered as an anathema and many voters quit the party or they decided not to vote. Table 4 shows the performance of PASOK in general elections since 2009.

In 2009 PASOK won the election with $43.93 \%$ of the vote. In the double elections of 2012, PASOK obtained the lowest-ever percentage of votes with $13.18 \%$ and $12.28 \%$ respectively. In 2015 a new leader was elected, but the party was split and faced fierce political competition because the previous leader and the prime minister left PASOK and in the 2015 elections participated with a new party, but was not successful in gaining the minimum 3\% of the popular vote to win seats in the Greek Parliament. However, he succeeded in attracting 152,557 votes, which of course all of them can be considered as votes for PASOK in the 2012 elections. 
Table 4. PASOK's Election Results, 2009-2019

\begin{tabular}{|c|c|c|c|c|c|c|}
\hline Year & PASOK Votes & Loss of Votes & $\%$ & Turnout & Abstention & Abstention (dif) \\
\hline 2009 & 3012542 & & 43.92 & 7044606 & 2884459 & \\
\hline 2012 & 833452 & -2179090 & 13.18 & 6476751 & 3469108 & 584649 \\
\hline 2012 & 756024 & -77428 & 12.28 & 6216798 & 3731078 & 261970 \\
\hline 2015 & 289469 & -466555 & 4.68 & 6330356 & 3619328 & -111750 \\
\hline 2019 & 457623 & 168154 & 8.1 & 5769542 & 4192719 & 573391 \\
\hline
\end{tabular}

In addition, there was a new party which ideologically was very close to PASOK, called POTAMI, which was able to meet the requirement of $3 \%$ by gaining 373,924 votes. These two events brought PASOK into the 2015 general elections in its worse performance ever. In the 2019 elections, these two parties joined with PASOK as one coalition party and won $8.1 \%$ of the popular vote. The new primary elections of 2021 are considered by many as the last opportunity to revive PASOK to its past glory of a ruling party. This aspect is examined in the next section but in the remaining of this section, some comments are made regarding the previous intra-party elections as shown in Table 3.

\section{The First Election of a Leader by the Party Congress in 1996}

The first intra-party election to select a leader was made on $30^{\text {th }}$ June 1996 during a party congress with the participation of 5,111 elected congress members ${ }^{13}$. As mentioned in the second section, this was an indirect way to elect a leader. Party members elected the congress delegates, who in turn, voted for the next leader. With very few exceptions, my guess estimate is that there were no more than $5 \%$ of the delegates, and the rest of the delegates were committed to vote for one of the two candidates. This was known to all party members. Thus, a party member will vote for those delegates who were committed to vote for one of the two candidates. The result was very close. The winner got $53.77 \%$ of the congress members. Despite this, the party was not split; it remained united and as a result won the next general elections which took place during the same year (in 1996).

The two candidates were split on ideological grounds, but this was not so important as many congress members were emphasizing in their private deliberations. Most were motivated by self-interest and self-centered motivations of clientelism and nepotism. The two candidates had strong personal ambitions not only to lead the party but, at the same time, become the prime minister of Greece. One of the two candidates was already the prime minister selected by PASOK's members of parliament in a very close race to replace the sick Andreas G. Papandreou who resigned from prime minister but not from the position of the

\footnotetext{
${ }^{13}$ The big issue discussed in this period was the uncertainty of Greece's participation in the Eurozone. All candidates supported the Euro, but neither of them realized the difficulties of adjusting. I have examined elsewhere the problems of Greece's participation in the Eurozone, and in general, its economic problems including tax evasion, agricultural and small and medium sized enterprises; see Papanikos (2015a, 2004a, 2004b) and Papadopoulos and Papanikos (2005).
} 
party leader. As a matter of fact, Papandreou was preparing his participation for the party congress of 30 June 1996 but he died one week earlier, on 23 of June 1996.

During the party congress the participants were facing a dilemma. It was possible to select a leader of the party who would be different from the prime minister, but the prime minister at the time, and the candidate for the party leadership, declined in a very controversial and emotional speech. In front of all of the congress members, he stated that if he were to lose the intra-party elections he would resign from prime minister. Since he won the elections and became the leader of the party, nobody could tell whether this threat was a real one or a bluff to win some party members who were undecided. Real or not, given the closeness of the result, some congress members were influenced. They voted after taking the threat as a serious one. They rightly assumed that the two candidates did not have the same chances to win the next elections and therefore they voted for the one with the higher probability. This might have determined the result.

This very much relates to the three criteria of choosing a candidate. Even though this was not a primary election, it nevertheless can be considered as one because of the great majority of congress members who were elected by party members solely on the grounds of who of the two candidates would support a party leader. Very few, and I assume less than 5\%, were indecisive and were considered independent.

Many voters in the congress had an ideological preference, but most importantly a self-interest to select a candidate who had the highest possible probability to win the next general elections. The perception among the independent congress members was that one candidate was good as a prime minister because they appealed to a wider spectrum of voters mainly from the center-right. The other was considered good as a party leader and many would have chosen him as a party leader if the viability (preference) effect was more powerful than the electability effect. Thus, there were two effects: the preference effect and electability effect. It seems that the latter dominated. As it turned out, the elected leader and prime minister not only won the next general elections in 1996, but the following one in 2000 as well.

\section{The Primary Elections of 2004}

By the end of 2003, the popularity of PASOK as a ruling party was declining and just before the election of March 2004, the prime minister resigned from party leader and for the first time a primary elections process was adopted to elect the new leader. However, this could not be considered an election because there was only one candidate: the son of the founder of PASOK.

Nobody else dared to submit an application to be a candidate. Despite this, the party elite decided to hold the primaries. After all, there was a choice of a void ballot. Only $0.3 \%$ chose to cast a void ballot; the rest overwhelmingly voted for the one candidate, giving him an approval of $99.7 \%$. The winner and his supporters were cheering for the great number-over a million-who turned out and voted. Anecdotal evidence supports the hypothesis that there was a mass fraud 
and the actual number was less than one-third of that which was reported. However, it was a good political marketing tool for the next general elections which were held on 7 March 2004. PASOK lost, but the loss was a respected one with $3,003,275$ voters, or $40.55 \%$. The winning right-wing party got $45.36 \%$ and formed a government.

The experience of the primary elections was unique. It was positively accepted by all voters of all parties. This forced the right-wing ruling party to adopt the same electoral system a few years later.

\section{The Primary Elections of 2007}

PASOK lost the elections of 2007 but retained the percentage of votes as in the 2004 election. A new primary election was called. This time there were three candidates including the existing leader who ran again. Relative to the 2004 primary elections (see Table 3), fewer voters turned out in the 2007 elections despite the fact there was strong political competition. The result reinstated the current leader who led PASOK to victory in the next elections of 2009. However, because of the crisis and the many mistakes he made, he decided to step down from prime minister and the leader of PASOK.

\section{The Primary Elections of 2012}

On the $18^{\text {th }}$ March 2012, PASOK had yet another primary election but only one candidate ran for the position of president. The number of people who voted was 236,151. The new leader participated in the double elections of 2012 and participated in a coalition government, 2012-2015. It is important to note that the double elections of 2012 were fought on a number of issues. Three were very important as shown in Table 5.

Apart from ideology, the most important issue was whether Greece could stay in the Eurozone without the need of austerity measures. As turned out, this was not possible.

Table 5. Typology of Issues

\begin{tabular}{|l|c|c|}
\hline Issue & \multicolumn{2}{|c|}{ Options } \\
\hline Ideology & Center-Right & Center-Left \\
\hline Eurozone-European Union & Pull out & Stay in \\
\hline Austerity Measures & Necessary & Not Necessary \\
\hline
\end{tabular}

\section{The Primary Elections of 2015}

PASOK did very bad in the elections of 2015 and as a result the leader stepped down. In a new primary election, a new leader was elected, and for the first time a woman ran the party. She successfully brought all various factions into the party, which have demonstrated ideological proximity and agree on basic strategies and policies as are shown in Table 5. After this process, it was considered imperative to hold new primary elections. 


\section{The Primary Elections of 2017}

New primary elections were called to elect the leader of the coalition on the $12^{\text {th }}$ November 2017 . This time no candidate was able to get more than $50 \%$ of the vote. The leader was elected between the first two in a second round. In this case there were splits and those who lost decided to follow an independent political course or join other parties. By this time, PASOK had gained experience in organizing primary elections and the most recent one is discussed in the next section.

\section{The Primary Elections of 2021: The Ideology}

The primary elections were held on $5^{\text {th }}$ and $12^{\text {th }}$ December 2021 where six candidates were running for office. One of the issues was the ideology of the candidates and the ideology of voters. The latter was unknown because the electoral system was open. Members and friends could come on the day of the vote, register and then vote. Members of other parties were not allowed, but friends of other parties could vote and this was an important factor because PASOK lost many voters in the last decade that opted to vote for parties to the left and to the right of PASOK. According to various polls conducted prior to primary elections, $44 \%$ of the total Greek voters declared that could vote again PASOK; this was the percentage of votes PASOK won in the 2009 general elections. Compare this with the $8 \%$ of the previous general elections of 2019 ; if all the $44 \%$ voters could turn out on the ballot date of the primaries, then the effect would have been much different. The reason for abstaining might be that they are not very keen to vote in primaries. As I said in the previous section, the turnout in 2004 of more than one million voters most probably was the result of fraud rather than an actual number.

\section{The Ideology of the Three Leading Candidates}

The ideology of the candidate is one of the most important characteristics that voters have taken into consideration in deciding who to vote for in a primary election. In the 2021 PASOK's primary election this became an important issue and a topic of debate and discussion. In Figure 2 the three leading candidates are depicted according to their ideologies as this was perceived by voters and the mass media during the election campaign of each candidate. It is important to note that no candidate openly declared his ideology. Therefore, voters and the mass media were using a signaling extracting process which mainly consisted of a possible future collaboration with political parties, which on the ideological spectrum are located left and right of PASOK (the vertical lines in Figure 2). 
Figure 2. The Ideological Location of the Three Leading Candidates

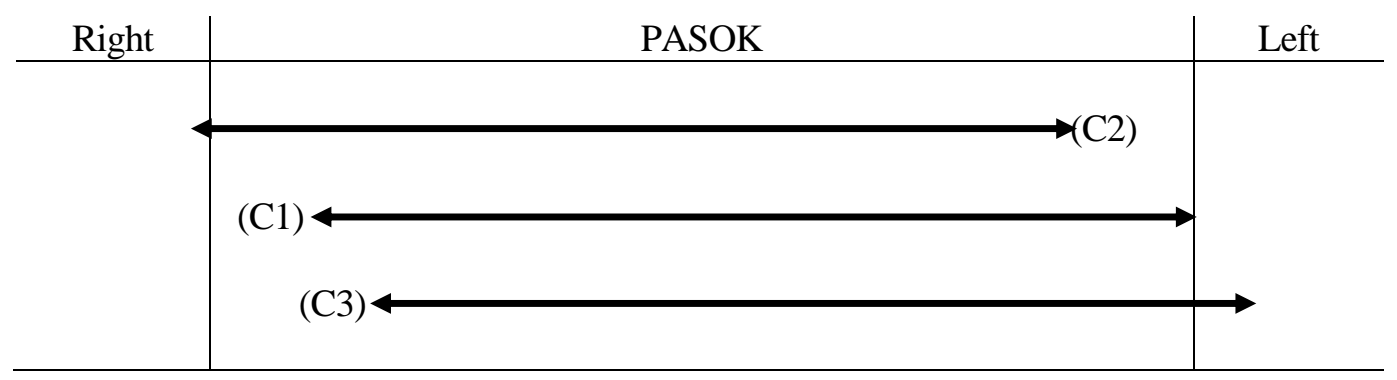

C1: Androulakis; C2: Loverdos; C3: Papandreou.

\section{The Ideology of Voters}

Figure 3 shows the ideology of voters in the primary elections where three types of voters are distinguished. All are determined according to their attitudes towards the left-wing and the right-wing opposing to PASOK parties. From an ideology point of view, PASOK stands in the middle of the governing party (rightwing) and the official opposition party (left-wing). PASOK is the third party in the Greek Parliament. Firstly, they are those voters whose ideology is close to the rightwing party and therefore they would not have a problem in collaborating with them to form a coalition government. Secondly, they are those whose ideology is close to the left-wing party and they would feel comfortable collaborating with them. Thirdly, they are those who oppose any collaboration with either the left-wing or the right-wing parties of Greece.

The primary election results during the first round can be interpreted as confirming this depiction of voters' ideology. This is discussed in the following section.

Figure 3. The Venn Diagram of Party Members' and Friends' Attitudes Towards the Other Parties Left and Right Ideologies

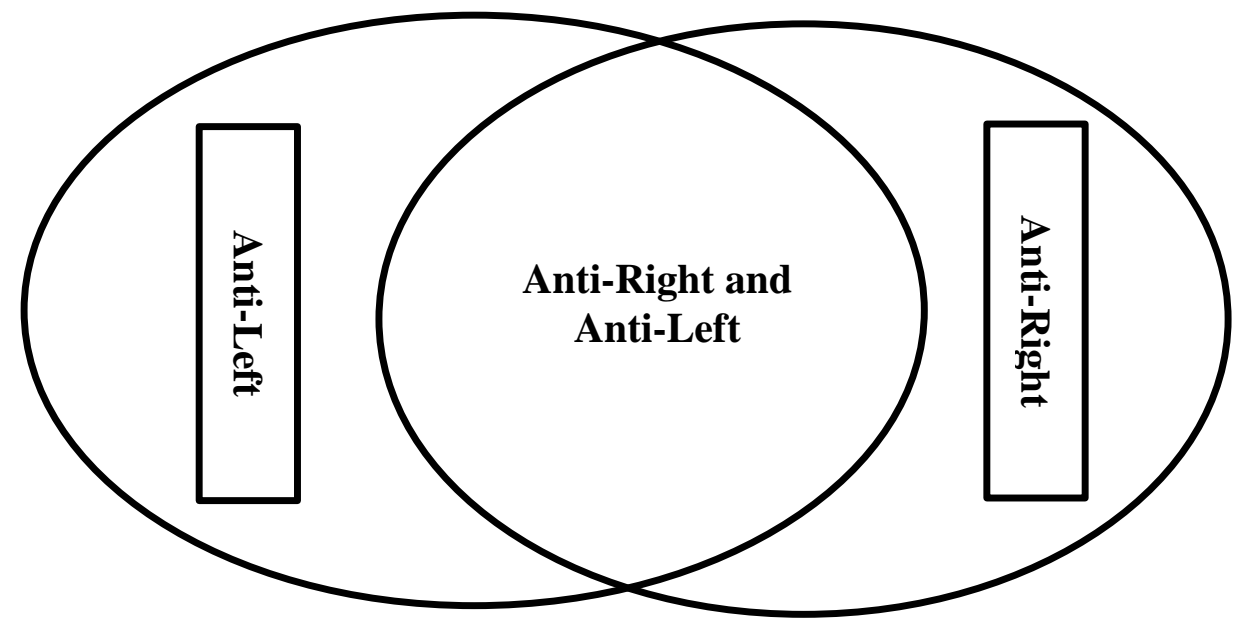




\section{The Primary Election of 2021: Results and Discussion}

In the 2021 primary elections of PASOK an open system was adopted. Only members of other parties were excluded from voting. Each voter had to fill out and sign a form stating that he/she was not a member of another party and they wanted to become members or friends of PASOK. Members of the other parties were not allowed to vote even though it was very difficult to distinguish between them. All voters can register on the same date that they vote by paying a fee of 3 euro. During the second round no fee was required, but only those who voted in the first round could participate in the second round as well.

Six candidates run for office but not all six candidates had the same motivation to run for the leadership race. There were two groups of candidates. Each group consisted of three candidates. The first group included the favored to win the race. The three candidates with the higher probabilities of success were the former prime minister of Greece George Papandreou (born in 1952), the second was Andreas Loverdos (born in 1956), a member of the Greek Parliament and Nikos Androulakis (born in 1979), an elected member of the European Parliament. All three candidates had run in previous primary elections and therefore had the experience. Only Papandreou had run two times before and won both times in 2004 and 2007. His case is of great interest and is further discussed in the next section.

The total number of party members and friends of PASOK who voted in the first round was 270,706 . The results of the first round of primary elections are reported in Table 6 . The total number of votes obtained by all six candidates was 268,798, of whom 266,347 voted in Greece and 2,451 in countries outside Greece.

A number of conclusions emerge from the results reported in Table 6. Firstly, despite all the media fuss about the renewal of the party, the election results show that voters overwhelmingly voted for older candidates. Three candidates were born in the 1950s, one in the 1960s, one in the last year of the 1970s (the winner) and the youngest in 1983. The average age was 56 years. If the group of candidates is split into young (two of them) and old (three of them), then close to $60 \%$ of voters chose old and close to $40 \%$ chose young candidates. However, I should mention that the youngest of all candidates did an excellent campaign. Even though he entered late in the race, he was able to get a respectable percentage of PASOK's voters. For many of the voters he was an unknown political figure, which is an additional advantage of primary elections; they give the opportunity to young and relatively inexperienced candidates to demonstrate that they deserve not only the party's attention but the general electorate as well. This "investment" in political exposure will bear its fruits pretty soon if it is managed appropriately.

Table 6. Results of the First Round of Primary Elections

\begin{tabular}{|l|c|c|c|c|c|c|}
\hline & Candidate & $\begin{array}{c}\text { Votes } \\
\text { Greece }\end{array}$ & $\begin{array}{c}\text { Votes } \\
\text { Global }\end{array}$ & $\begin{array}{c}\text { Votes } \\
\text { Total }\end{array}$ & Percentage & Birth Year \\
\hline 1 & Androulakis & 98431 & 689 & 99120 & $36.88 \%$ & 1979 \\
\hline 2 & Papandreou & 74093 & 1090 & 75183 & $27.97 \%$ & 1952 \\
\hline 3 & Loverdos & 69411 & 416 & 69827 & $25.98 \%$ & 1956 \\
\hline 4 & Christidis & 8642 & 91 & 8733 & $3.25 \%$ & 1983 \\
\hline
\end{tabular}




\begin{tabular}{|l|c|c|c|c|c|c|}
\hline 5 & Geroulanos & 7946 & 81 & 8027 & $2.99 \%$ & 1966 \\
\hline 6 & Kastanidis & 7824 & 84 & 7908 & $2.94 \%$ & 1956 \\
\hline Total & 266347 & 2451 & 268798 & $\mathbf{1 0 0}$ & $\begin{array}{c}\text { Avg Age }= \\
\mathbf{5 6}\end{array}$ \\
\hline
\end{tabular}

Playing the youth card in the political debate had a double meaning. PASOK's members and friends decided to pass over the leadership of the party to the new generation. However, this might be the result of either the old generation (over 60) voting for a young leader, and/or the youth of the party (under 40) voted for someone who had the same age. On the other hand, the winner was not involved with governmental responsibilities because of his age and therefore nobody was able to accuse him of wrongdoings.

Secondly, voters seem to have voted for mainstream ideology which stands on an independent course rather than collaborating with either the left or the right, but this should be interpreted with caution. If the party becomes great again and gets a high percentage of votes in the next general elections, then the issue of collaboration with other parties to form a government is not crucial. The issue becomes a real one if PASOK had no choice but to collaborate. Again, this might not be a critical issue if the general election results are such that there is only one choice, i.e., to collaborate with only one of the two parties. The real issue of choice is only when PASOK would have the option to collaborate with a left or a right political party. In 2012, PASOK had no choice but to form a coalition government with the right-wing parties even though in the beginning was a small left party that participated in the coalition. This is in contrast with SYRIZA in 2015 which had the choice to collaborate with two center-left parties (PASOK and POTAMI), but instead decided to collaborate with an extreme right-wing party to form a government from 2015 to 2019.

Autonomy and renewal were the slogan of the winner of this round of primary elections. Autonomy is an ideological stance while renewal was used to state the obvious, i.e., he was young.

Table 7 reports the results of the second round. As many had expected, the winner of the first round won the second round as well. Some comments are made which are guided by the literature review of the second section.

Table 7. Results of the Second Round of Primary Elections

\begin{tabular}{|l|c|c|c|c|}
\hline Candidate & $\begin{array}{c}\text { Votes } \\
\text { Total }\end{array}$ & Percentage & Birth Year \\
\hline 1 & Androulakis & 139,492 & 67.6 & 1979 \\
\hline 2 & Papandreou & 66,847 & 32.4 & 1952 \\
\hline \multicolumn{2}{|l}{ Total } & $\mathbf{2 0 6 , 3 3 9}$ & $\mathbf{1 0 0}$ & Age Difference = 27 years \\
\hline
\end{tabular}

From an ideology point of view, this was something to be expected because in terms of votes, the third candidate was closer to the winner's ideology in the first round. I do not want to overemphasize the issue of ideology because intra-party personal politics played a role as well in terms of factions which were more personal rather than ideological. 
The oldest candidate competed with the second youngest. The age difference was one generation, i.e., 27 years. This played the most important role. There was a general call to renew the party. They thought that by electing a relatively young candidate the probability of winning the next elections is higher. This is according to the criterion of electability mentioned in the literature. There is another interesting stylized fact which rarely occurs in primary system of two rounds. The second runner-up got fewer absolute votes in the second round relative to the first round. He obtained 74,093 votes in the first round and 66,847 votes in the second round. My interpretation is that this occurred because of the electability argument. Many voters considered that he failed to mobilize as many votes as they expected from him in the first-round and therefore, he had no chance to bring more votes from the general electorate to win the next general elections. They chose to abstain. Of course, this assumes that they did not believe that the winner was a good choice either. More on Papandreou's chances to win the primaries is discussed in the next section.

The other selection criterion was viability, i.e., who the party members would feel closer to their own preferences for a good leader of the party. The winner served in the past as the General Secretary of the party and had persuaded many partisans that he had the skills to run the party effectively.

In conclusion, it seems that the criteria set by the literature review explain the results of the second round.

\section{George A. Papandreou's Chances of Success}

This section is devoted to Papandreou's candidacy because his case has great theoretical interest. In the literature review section, it was mentioned that one of the reasons parties organize primary elections is to either avoid or integrate splits. This is the case with Papandreou's candidacy and is further discussed in the remaining section of this paper.

Papandreou entered the race late compared with his main opponents. He decided to run just before the unexpected death of PASOK's leader on $25^{\text {th }}$ October 2021. She was also planning to run to be reelected but due to serious health reasons, quit. After this, Papandreou decided to run again for the presidency of the party. Despite his lateness, he was in a better position if he could mobilize his followers. As a matter of fact, Papandreou's problem was not the loyal supporters and friends of all other candidates, but his own large niche of supporters. Papandreou's problem was to mobilize the members of his own faction. I assume that the others had no problem in mobilizing their supporters because they have been working for their candidacy for more than two years.

On $25^{\text {th }}$ January 2015, Papandreou competed in the general elections with his own party after splitting from PASOK despite the fact that (a) his father was the founding member of PASOK; (b) he was an elected member of parliament since a very early age (under 30); (c) became the leader of the party in 2004, and as a result (d) the prime minister in 2019. 
In 2015, he was unable to win parliament seats because he did not get the required minimum percentage of $3 \%$ of total votes. He obtained $2.47 \%$ or 152,557 votes. Thus, he had only one task: to mobilize these loyal followers to turnout on the date of the primary election and vote for him. This would have given him a probability of success from the first round.

According to my guess estimates which were published as a small working paper on $30^{\text {th }}$ October 2021 (Papanikos 2021), Papandreou would have an easy ride and win the leadership race if he could mobilize his supporters. As expected from the theoretical literature, his candidacy increased the mass media attention; not only the Greek but the international as well because Papandreou was the President of the Socialist International. My assumption was that Papandreou would bring new and old friends into the group of voters.

Following a rule of thumb approach, I estimated a critical value of 300,000 voters. If the turnout was more than this number, then Papandreou would win not only the first round but the second round as well. Some other assumptions were not as critical, e.g., (a) the Papandreou's political brand name would bring him an additional $10 \%$ of the total vote and (b) supporters of the deceased president of PASOK would vote for Papandreou as well; I assumed that $30 \%$ to $40 \%$ of this block of party supporters would vote for Papandreou. Table 8 reports the actual votes and their percentage per candidate, and the percentage of votes per candidate for three scenarios: 400,000 voters, 350,000 voters and 300,000 voters.

Table 8. Three Scenarios of Papandreou's Potential Win (see Papanikos, 2021) ${ }^{14}$

\begin{tabular}{|c|c|c|c|c|c|c|}
\hline & Candidate & $\begin{array}{c}\text { Actual } \\
\text { Votes }\end{array}$ & Percentage & $\begin{array}{c}\text { Scenario A } \\
400,000\end{array}$ & $\begin{array}{c}\text { Scenario B } \\
\mathbf{3 5 0 , 0 0 0}\end{array}$ & $\begin{array}{c}\text { Scenario C } \\
\mathbf{3 0 0 , 0 0 0}\end{array}$ \\
\hline 1 & Androulakis & 99120 & $36.88 \%$ & $24.8 \%$ & $28.3 \%$ & $33.0 \%$ \\
\hline 2 & Papandreou & 75183 & $27.97 \%$ & $51.6 \%$ & $44.7 \%$ & $35.5 \%$ \\
\hline 3 & Loverdos & 69827 & $25.98 \%$ & $17.5 \%$ & $20.0 \%$ & $23.3 \%$ \\
\hline 4 & Christidis & 8733 & $3.25 \%$ & $2.2 \%$ & $2.5 \%$ & $2.9 \%$ \\
\hline 5 & Geroulanos & 8027 & $2.99 \%$ & $2.0 \%$ & $2.3 \%$ & $2.7 \%$ \\
\hline 6 & Kastanidis & 7908 & $2.94 \%$ & $2.0 \%$ & $2.3 \%$ & $2.6 \%$ \\
\hline & Total & 268798 & 100 & 100 & 100 & 100 \\
\hline
\end{tabular}

The best scenario of Papandreou would have been to mobilize the maximum of all his loyal supporters which could have increased the total turnout to 400,000. In this case Papandreou would have won from the first round with 51.5\%. As a matter of fact, in the primary elections of 2015, the president of PASOK was elected from the first round with almost the same percentage of $51.7 \%$. On the other hand, if he could have mobilized his supporters so the total turnout would have been 350,000 , then Papandreou would have obtained the $44.7 \%$ of total ballots casted. Finally, at the threshold level of 300,000, Papandreou would have come first with $35.5 \%$ of votes and the second would have received $33 \%$.

Papandreou failed to mobilize all his supporters. As a result, the overall turnout was less than $10 \%$ of the threshold of 300,000 voters. Thus, this

\footnotetext{
${ }^{14} \mathrm{https} / / /$ www.researchgate.net/publication/356529365_Oi_Ektimeseis_gia_ten_Ekloge_Proedrou_t ou_PASOK_stis_Epikeimenes_Ekloges_stis_5_e_kai_12_Dekembriou_2021/
} 
precondition was not satisfied and Papandreou did not come first in the first round, but got the second position which permitted him to participate in the second round. The point I wanted to make was that if he could have mobilized his 2015 voters, he would have had a chance of winning the elections even from the first round.

\section{Conclusions}

Primary elections make democracy better. As in Ancient Athens, citizens (those who have the right to vote) express their opinion on who they want to run their party. By doing so, and if all ruling parties do so, then who runs for public office is the peoples' choice. PASOK was the first Greek political party which instigated primary elections. Immediately the opposition center-right party followed by adopting primary elections.

This paper examines PASOK's primary election, discussing further the most recent one of December 2021. As would have been predicted by the relevant theoretical literature on primary elections, ideology and party renewal did play a role. The aim to keep the party united is too early to tell, but even if one of the candidates attempt to split the party, the chances that he will be successful are very slim.

In Greece primary elections have been welcome with enthusiasm. An unexpected number of citizens turn out to vote. It is expected that not only the system of electing leaders will remain but it will expand towards two directions. Firstly, other parties will adopt the same system, especially those which attract a relatively high number of popular votes. Secondly, the primary system will be expanded to other issues and elections. For example, primaries can be held for important decisions to be made or to elect the members of party elite. It seems that democracy will have a snowballing effect and reverse the long-observed apathy of citizens. One may conclude that primaries serve two purposes. Firstly, political parties would become better by becoming more democratic. Secondly, citizens would become better and accept democracy because they would like to be informed before they vote. Educating citizens is a precondition for a better democracy. Primary elections serve this objective and they are here to stay.

\section{Acknowledgments}

I would like to thank Professor Yannis Stivachtis for his constructive comments in an early version of this paper. This paper was presented at the Symposium on Democracy organized as part of the 15th Annual International Conference on Global Studies: Business, Economic, Political, Social and Cultural Aspects organized by the Business, Economics and Law Division and the Economics Unit of ATINER on the $20^{\text {th }}$ December 2021 in Athens, Greece. I would like to thank all the participants. Finally, I would like to thank many friends with whom I had many informal discussions on the primary elections of PASOK. Some of their thoughts and comments are included in this paper. 


\section{References}

Abramowitz AI (1989) Viability, electability, and candidate choice in a presidential primary election: a test of competing models. The Journal of Politics 51(4): 977-992.

Aragón FM (2014) Why do parties use primaries? Political selection versus candidate incentives. Public Choice 160(1-2): 205-225.

Bochel J, Denver D (1983) Candidate selection in the labour party: what the selectors seek. British Journal of Political Science 13(1): 45-69.

Bonica A (2013) Ideology and interests in the political marketplace. American Journal of Political Science 57(2): 294-311.

Carroll R, Kubo H (2019) Measuring and comparing party ideology and heterogeneity. Party Politics 25(2): 245-256.

Cross WP, Kenig O, Pruysers S, Rahat G (2016) The promise and challenge of party primary elections: a comparative perspective. Montreal: McGill-Queen's University Press.

Curini L (2015) Explaining party ideological stances. Public Choice 162(Sep): 79-96.

Downs A. (1957) An economic theory of democracy. New York: Harper \& Row Publishers.

Faucher F (2015) New forms of political participation: changing demands or changing opportunities to participate in political parties? Comparative European Politics 13(4): 405-429.

Hall AB, Thompson DM (2018) Who punishes extremist nominees? Candidate ideology and turning out the base in US elections. American Political Science Review 112(3): 509-524.

Herrmann M, Shikano S (2016) Attractiveness and facial competence bias face-based inferences of candidate ideology. Political Psychology 37(3): 401-416.

Hopkin J (2001) Bringing the members back in? Democratizing candidate selection in Britain and Spain. Party Politics 7(3): 343-361.

Hortala-Vallve R, Mueller H (2015) Primaries: the unifying force. Public Choice 163 (34): 289-305.

IDEA (2017) The global state of democracy: exploring democracy's resilience. Stockholm: International IDEA.

Kaufmann KM, Gimpel JG, Hoffman AH (2003) A promise fulfilled? Open primaries and representation. Journal of Politics 65(2): 457-76.

Lundell K (2004) Determinants of candidate selection: the degree of centralization in comparative perspective. Party Politics 10(1): 25-47.

May JD (1973) Opinion structure of political parties: the special law of curvilinear disparity. Political Studies 21(2): 135-151.

Nielson L, Visalvanich N (2017) Primaries and candidates: examining the influence of primary electorates on candidate ideology. Political Science Research and Methods 5(2): 397-408.

Norrander B (1989) Ideological representativeness of presidential primary voters. American Journal of Political Science 33(3): 570-587.

Papadopoulos AP, Papanikos GT (2002) Exchange rate regimes and the linkage between money and output in Greece. Journal of Policy Modelling 24(2): 103-117.

Papadopoulos AP, Papanikos GT (2005) The determinants of vinegrowers employment and policy implications: the case of a Greek island. Agricultural Economics 32(1): 61-72.

Papanikos GT (2004a) The determinants of employment creation in small regional firms. International Regional Science Review 27(2): 187-204. 
Papanikos GT (2004b) Regional convergence in Greece in the 1980s: an econometric investigation. Applied Economics 36(8): 881-888.

Papanikos GT (2014a) The Greek economic crisis: a class analysis in support of memorandums (in Greek). Athens, Greece: ATINER.

Papanikos GT (2014b) Greek trade unions, the euro and the current crisis. The Singapore Economic Review 59(4): S1-S2.

Papanikos GT (2014c) The Greek sovereign debt: are there really any options? Romanian Journal of Fiscal Policy 5(2): 1-25.

Papanikos GT (2015a) The real exchange rate of euro and Greek Economic growth. Journal of Economic Asymmetries 12(Nov): 100-109.

Papanikos GT (2015b) Taxing wealth and only wealth in an advanced economy with an oversized informal economy and vast tax evasion: the case of Greece. Vierteljahrshefte zur Wirtschaftsforschung, DIW Berlin 84(3): 85-106.

Papanikos GT (2015c, May 27) A Grexit would not be a catastrophe for all. LSE European Politics and Policy (EUROPP) Blog.

Papanikos GT (2015d, April 13) The Greek economic crisis: facts and myths. Available at: http://www.atiner.gr/gtp/The Nature of Greek Economic Crisis.pdf

Papanikos GT (2015e, March 4) The long and winding road to reform Greece's economy. The Conversation.

Papanikos GT (2015f, February 4) Greece's new debt deal may appease creditors but it won't help the economy. The Conversation.

Papanikos GT (2015g, January 26) The "Works and Days" of Syriza's first week in power. Available at: http://www.atiner.gr/gtp/The Works and Days of Syriza's first week in power.pdf.

Papanikos GT (2015h, January 26) With Greece backing euro but Syriza in government, another election may beckon. The Conversation and New Statesman.

Papanikos GT (2015i, January 22) ECB decision should be good news for Greece, but Syriza will get in the way. The Conversation.

Papanikos GT (2015j, January 6) Hard evidence: can Germany throw Greece a lifeline and save the euro? The Conversation.

Papanikos GT (2019) Andreas G. Papandreou: economist and prime minister (in Greek). Athens, Greece: ATINER.

Papanikos GT (2021, October 30) Estimates of electing the leader of PASOK in the forthcoming elections of 5 and/or 12 December 2021. Working Paper (in Greek). Available at: https://bit.ly/3GHJ6iv.

Shomer Y (2014) What affects candidate selection processes? A cross-national examination. Party Politics 20(4): 533-546.

Spies DC, Kaiser A (2014) Does the mode of candidate selection affect the representativeness of parties? Party Politics 20(4): 576-590.

Westley C, Calcagno PT, Ault R (2004) Primary election systems and candidate deviation. Eastern Economic Journal 30(3): 365-376.

Westley C, Calcagno PT (2005) Incumbent spending and gubernatorial elections: an investigation of primary type and candidate deviation. Journal of Public Finance and Public Choice 23(1-2): 3-18.

Williams DC, Weber SJ, Haaland, GA, Mueller RH, Craig RE (1976) Voter decision making in a primary election: an evaluation of three models of choice. American Journal of Political Science 20(1): 37-49. 